\title{
Groundwater governance in South Africa: A status assessment
}

\author{
K Pietersen ${ }^{1 *}$, HE Beekman ${ }^{1}$, M Holland $^{1}$ and S Adams ${ }^{2}$ \\ ${ }^{1} S L R$ Consulting (Pty) Ltd, Pentagon House, 669 Plettenberg Road, Faerie Glen, Pretoria, 0043, South Africa \\ ${ }^{2}$ Water Research Commission, Private Bag X03, Gezina, 0031, South Africa
}

\begin{abstract}
Groundwater governance provisions and arrangements in South Africa were studied at national level and at local level for a highly productive aquifer, the Botleng Dolomite Aquifer. Technical, legal, institutional and operational governance provisions were found to be reasonable at the national level but weak with regards to cross-sector policy coordination. At the local level, basic technical provisions such as hydrogeological maps and aquifer delineation with classified typology are in place but other governance provisions such as institutional capacity, provisions to control groundwater abstraction and pollution, cross-sector policy coordination and the implementation of a groundwater management action plan are weak or non-existent. Adaptation measures to climate change are not yet fully considered in planning. Only at the national level a groundwater strategy and artificial-recharge strategy has been developed but awaits implementation. Most critical management measures are considered, namely:

- The integration of the National Groundwater Strategy (NGS) into the various water-related strategies

- Strengthening of the groundwater regulatory environment

- Strengthening of the institutional capacity
\end{abstract}

Keywords: groundwater, governance, dolomite, South Africa

\section{Background and methodology}

This paper presents the results of a case study on groundwater governance in South Africa that formed part of the World Bank project: 'Too Big to Fail: The Paradox of Groundwater Governance'. Other case studies whose findings contributed to the project were conducted in India, Kenya, Peru, Morocco, Philippines and Tanzania.

The objectives of the project are to:

- Understand the impediments to better governance of groundwater, and to identify the opportunities for ensuring that groundwater forms a key element of integrated water resource management (IWRM) in developing countries

- Explore opportunities for using groundwater to assist developing countries in adapting to climate change

The South African groundwater governance case study was carried out at 2 complementary levels, namely at the national strategic planning level; and at the local institutional level:

- At the national level, an analysis was made of the policy, legal and institutional frameworks for groundwater provisions, knowledge and capacity availability and gaps, and financing arrangements to strengthen groundwater governance.

- At the local level, 4 highly productive aquifer systems demonstrating various degrees in the implementation of groundwater governance were analysed (Fig. 1) - Botleng Dolomite Aquifer (Delmas area); Gauteng Dolomites (Steenkoppies and Bapsfontein compartments); Houdenbrak Basement Aquifer (Mogwadi (Dendron)-Vivo area); and Dinokana-Lobatse Transboundary Dolomite Aquifer.

This paper was originally presented at the International Conference on Groundwater: Our Source of Security in an Uncertain Future, Pretoria, 19-21 September 2011.

* To whom all correspondence should be addressed.

용 +2712 991 8881; fax: +27 12991 1907; e-mail: kpietersen@slrconsulting.com
This paper presents the findings for the Botleng Dolomite Aquifer.

For each aquifer system the risk of potential threats (mostly related to exploitation and pollution) was assessed and the groundwater governance status determined following the pragmatic Foster et al. (2009) classification of groundwater issues. Based on a priority list of 20 benchmarking criteria (Foster et al., 2009), the effectiveness of technical, legal and institutional, cross-sector policy coordination and operational groundwater governance provisions and institutional capacity for implementation was assessed, based on which management measures were proposed to strengthen the groundwater governance status. The relevance of groundwater governance arrangements for coping with impacts of climate change was next reviewed according to a risk-based framework developed by SKM (2009).

The case study builds upon knowledge of the hydrogeology and groundwater management at the national and local aquifer levels gained through a large amount of work carried out in recent years. In particular, the National Groundwater Strategy (DWA, 2010) which addresses deficiencies in groundwater provisions in the National Water Resource Strategy (DWAF, 2004) and the Department of Water Affairs (DWA; formerly known as DWAF) Implementation of Dolomite Guideline Project Phase 1 (DWAF, 2006; WGC, 2007; 2008; 2009) proved to be invaluable sources of data and information.

\section{Review of provisions at national level}

The first democratically elected non-racial Government of South Africa took office following the elections of 1994. This newly elected Government demonstrated strong political will to implement sustainable water development through sound water governance in the context of IWRM and this led to major reforms in water policies and institutions. The National Water Act (NWA; Act 36 of 1998) which has grown out of the National Water Policy of 1997 became the cornerstone of groundwater governance in South Africa and is based on the 


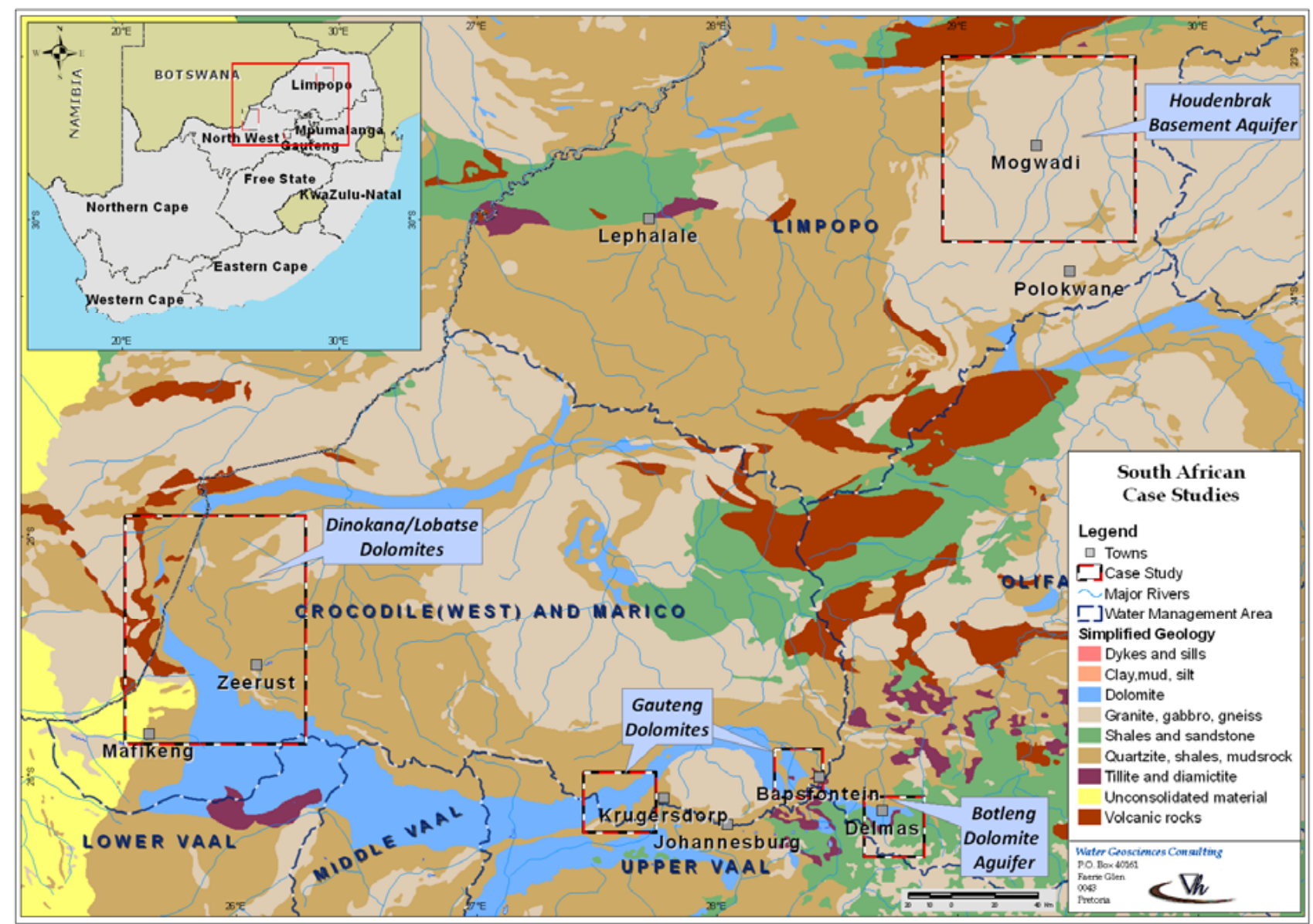

Figure 1

Location of selected aquifers

3 pillars of social equity, economic efficiencies and environmental sustainability. The fundamental principles and objectives of South Africa's water law with implications for groundwater are that:

- All water resources are common to all (water considered as a public asset), and are subject to national control (trusteeship vested in the state).

- All water has a consistent status in law, irrespective of where (and where in the water cycle; includes groundwater) it occurs.

- Groundwater is an integral part of the water resource and must be managed as such (supporting the principles of IWRM: groundwater should not be seen in isolation).

In accordance with the National Water Policy (NWP; DWAF, 1997) and the National Water Act (1998), the National Water Resource Strategy (DWAF, 2004) describes in general terms how South Africa's water resources should be 'protected, used, developed, conserved, managed and controlled'. Table 1 presents an overview of groundwater provisions in South Africa's National Water Policy. Overall, groundwater provisions are well catered for in the NWP.

In 2007, the Department of Water Affairs (DWA) began the process of formulating a National Groundwater Strategy (DWA, 2010). The NGS addresses shortcomings in groundwater provisions in the $1^{\text {st }}$ edition of the National Water Resource Strategy (NWRS) (DWAF, 2004) and serves as input to the $2^{\text {nd }}$ edition of the NWRS which is due in 2012. Table 2 presents shortcomings in groundwater provisions in the NWA and first edition of the NWRS.

The following issues/weaknesses were identified with regards to South Africa's institutional framework for the water sector; knowledge and capacity; water-sector financing; and climate change and adaptation:

\section{Institutional framework}

- National:

- Inadequate co-ordination with and support to regional offices and municipalities

- Regional:

- Delay in establishing CMAs, lack of updating of internal strategic perspectives (ISPs), delay in formulation and implementation of catchment management strategies (CMSs); (ground)water issues not adequately taken care of in integrated development plans (IDPs) at local level

- International (SADC):

- Weak institutional framework (river-basin organisations to be better aligned to national programmes; Groundwater Management Institute of Southern Africa still not operational)

\section{Knowledge and capacity}

- Knowledge

- Inadequate information on groundwater

- Delay in replacing the National Groundwater Database 


\begin{tabular}{|c|c|}
\hline \multicolumn{2}{|r|}{$\begin{array}{c}\text { Table } 1 \\
\text { Groundwater provisions in South Africa's National Water Policy }\end{array}$} \\
\hline Topic & Groundwater provisions \\
\hline $\begin{array}{l}\text { Rights and access to } \\
\text { groundwater }\end{array}$ & $\begin{array}{l}\text { - All water part of interdependent water cycle; a resource common to all } \\
\text { - Equity in access for all South African citizens to water services, water resources and benefits from } \\
\text { usage } \\
\text { - No ownership but only a right for environmental and basic human needs (Reserve) and } \\
\text { authorisation for its use }\end{array}$ \\
\hline Groundwater allocation & $\begin{array}{l}\text { - Allocation licensing policy (registration of new wells, drillers; groundwater use in context of } \\
\text { catchment management plan) }\end{array}$ \\
\hline $\begin{array}{l}\text { Protection of water } \\
\text { resources }\end{array}$ & $\begin{array}{l}\text { - Resource directed measures - setting clear objectives for protection of resources (classification, } \\
\text { Reserve determination and resource quality objectives, RQOs; DWAF, 2000) } \\
\text { - Source-directed measures - control and ensure that objectives are met } \\
\text { - Artificial recharge strategy (DWAF, 2007) }\end{array}$ \\
\hline $\begin{array}{l}\text { Climate change impacts } \\
\text { and adaptation }\end{array}$ & - Develop pro-active and pre-emptive approaches in water-related disaster prevention \\
\hline $\begin{array}{l}\text { Conjunctive use and } \\
\text { management }\end{array}$ & $\begin{array}{l}\text { - Water conservation and utilisation policy } \\
\text { - Water development in accordance with integrated environmental management }\end{array}$ \\
\hline Groundwater monitoring & - Detailed account of resource monitoring and information management \\
\hline Water pricing & - Water pricing policy \\
\hline $\begin{array}{l}\text { Transboundary water } \\
\text { management }\end{array}$ & - Southern African Development Community (SADC) Protocol on Shared Water Course Systems \\
\hline $\begin{array}{l}\text { Institutions for water } \\
\text { management }\end{array}$ & - National (DWA), regional (catchment management agencies; CMAs) and local (irrigation boards) \\
\hline Stakeholder participation & - Integral part of South Africa's water sector reform \\
\hline
\end{tabular}

\begin{tabular}{|c|c|}
\hline \multicolumn{2}{|r|}{$\begin{array}{c}\text { Table } 2 \\
\text { Shortcomings in groundwater provisions in NWA and } 1^{\text {st }} \text { edition of NWRS }\end{array}$} \\
\hline Topic & Shortcomings in groundwater provisions \\
\hline $\begin{array}{l}\text { Controlling groundwater } \\
\text { use }\end{array}$ & $\begin{array}{l}\text { - Licensing of groundwater unclear (regulation of local governments) } \\
\text { - Only } 20 \% \text { of applications processed } \\
\text { - Limited capacity within DWA }\end{array}$ \\
\hline $\begin{array}{l}\text { Regulating construction of } \\
\text { wells and boreholes }\end{array}$ & $\begin{array}{l}\text { - No explicit regulation } \\
\text { - Only technical guidelines and procedures for drilling, testing and sampling }\end{array}$ \\
\hline $\begin{array}{l}\text { Controlling groundwater } \\
\text { pollution }\end{array}$ & $\begin{array}{l}\text { - Waste discharge charge system not yet implemented } \\
\text { - Inadequate groundwater monitoring networks }\end{array}$ \\
\hline $\begin{array}{l}\text { Linkages with other legis- } \\
\text { lation, National Environ- } \\
\text { mental Management Act } \\
\text { (1998) and Minerals and } \\
\text { Petroleum Resources } \\
\text { Development Act (2002) }\end{array}$ & $\begin{array}{l}\text { - DWA and Department of Environmental Affairs (DEA) may require groundwater users to obtain a } \\
\text { licence and environmental authorisation } \\
\text { - The } 2 \text { departments follow different procedures for assessment } \\
\text { - No effective co-operative governance procedures in place } \\
\text { - Mines operating without water-use licences } \\
\text { - Mining permits issued without due consideration for water-use consequences }\end{array}$ \\
\hline
\end{tabular}

by the National Groundwater Archive

- Inaccessibility of data (especially those held by the private sector)

- Registration of drillers (to improve quality of borehole construction and data collection)

- Weak institutional arrangements for data collection and databases

- Incompatibility of various databases and information systems

- Capacity

- National government: shortage of hydrogeological staff and shortage of skills

- Local Government: no groundwater expertise

- Private sector: experienced groundwater boom since the late $1990 \mathrm{~s}$

- South Africa's institutions of higher learning: weak cooperation among institutions

\section{Water-sector financing}

- Total cost of implementing the NGS over the next period of 5 years $\sim$ R340 million

- Total cost of not implementing the NGS at least 1 (10 times more) if not 2 (100 times more) orders of magnitude higher than the cost of implementing the NGS

\section{Climate change and adaptation}

- At national and local level, adaptation measures to climate change are not yet fully considered in planning. An artificial recharge strategy has been developed at national level only and awaits implementation.

\section{Review of provisions at local level}

The Botleng Dolomite Aquifer is used as an example to describe the methodology followed in the groundwater governance provisions and arrangements analysis. The Botleng 
Dolomite Aquifer (Fig. 1) is the main source of water for largescale agricultural irrigation and for domestic use by the Delmas community. The small town of Delmas in the Mpumalanga Province with approximately 59000 residents is situated in one of the productive maize-growing areas of South Africa. However, the quality of the groundwater has become a matter of great concern with a number of diarrhoea and typhoid outbreaks over the past 2 decades (Mthethwa, 2008). In 2008, the DWA signed a contract for the supply and laying of a water pipeline to the town of Delmas to import potable water, supplied by Rand Water. Although the pipeline is one of the measures to prevent the outbreak of waterborne diseases, it will only partially solve the problem. Management of the Botleng Dolomite Aquifer by the local and national authorities could well serve as a benchmark in the management of groundwater resources in the more rural areas of South Africa.

\section{Resource setting}

Key characteristics of the Botleng Dolomite Aquifer and its usage are as follows:

Karst aquifer:

- Unconfined conditions

- Groundwater levels: $1.2 \mathrm{~m}$ bgl to $78 \mathrm{~m} \mathrm{bgl}$

- Storativity: $1 \%$ to $5 \%$

- Transmissivity: several hundred $\mathrm{m}^{2} / \mathrm{d}$

- Recharge: $8 \%$ to $12 \%$ MAP (670 mm)

- Highly vulnerable to pollution

Groundwater use:

- Large-scale agricultural irrigation and domestic use by Delmas from well-fields

- Potable water demand Delmas: $16 \mathrm{M} \ell / \mathrm{d} 10 \mathrm{M} \ell$ from wellfields and $6 \mathrm{M} \ell$ from the Rand Water pipeline

- Future water demand: $21 \mathrm{M \ell} / \mathrm{d}$ by 2015

The effectiveness of the Delmas Local Municipality and the DWA Regional Office has been weak in terms of groundwater management and protection. This is evidenced by the diarrheal outbreaks related to groundwater pollution from various anthropogenic sources. Also the current IDP does not take into account measures to protect groundwater resources. Table 3 presents an overview of typologies and threats to the Botleng Dolomite Aquifer.

\section{Local groundwater management}

The CMA responsible for the management of water resources in the Olifants Water Management Area, which encapsulates the Botleng Dolomite Aquifer, has not yet been established and as a result the regional office of the DWA acts as the interim CMA. The Delmas Local Municipality forms part of the Nkangala District Municipality and is the responsible Water Services Authority (WSA) supplying water from the Botleng Dolomite Aquifer. Groundwater supply is augmented by water from Rand Water. The National Health Act (No. 61 of 2003) assigns responsibility for municipal health services to metropolitan and district municipalities and includes waterquality monitoring. The Nkangala District Municipality has the responsibility for water-quality monitoring in the Delmas Municipal area (Kolisa, 2006).

Access to water is a constitutional right. The government policy currently defines this as $6 \mathrm{k} \ell$ /household $\cdot$ month. The total backlog in providing water services in 1994 was 17863 persons. This backlog has since been cleared with all residents receiving water services above the standards defined in terms of the Reconstruction and Development Programme (RDP). Water-quality management, however, remains an issue. The municipality did not adhere to the call to be assessed in terms of DWA's Blue Drop certification process. In terms of the Green Drop certification process an average score of $52 \%$ was achieved, and several areas were identified which need to be improved (DWA, 2009).

The development of the IDP is supported by a publicparticipation process. The Municipal Systems Act (No. 32 of 2000) requires municipalities to promote public participation and to build the capacity of residents, councillors and municipal officials to engage in participatory processes (DPLG, 2009). In the case of the Delmas Local Municipality IDP process, ward participatory meetings culminated in an IDP forum which included representation of the different political parties, various government agencies, business representatives, traditional leaders, youth organisations, etc. The representation of these organisations facilitated feedback to their various constituencies, and resulted in prioritisation of issues, identification of projects and evaluation in terms of their relevance.

A groundwater management plan for the Delmas Local Municipality was developed using baseline information for the aquifer system and included both water-quantity and

\begin{tabular}{|c|c|c|c|c|}
\hline \multicolumn{5}{|c|}{$\begin{array}{c}\text { Table } 3 \\
\text { Typologies and threats to the Botleng Dolomite Aquifer }\end{array}$} \\
\hline Typology & Situation / process & $\begin{array}{l}\text { Low } \\
\text { risk }\end{array}$ & $\begin{array}{c}\text { Medium } \\
\text { risk }\end{array}$ & $\begin{array}{l}\text { High } \\
\text { risk }\end{array}$ \\
\hline \multirow{3}{*}{$\begin{array}{l}\text { Risk of extensive quasi- } \\
\text { irreversible aquifer degradation } \\
\text { and subject to potential conflict } \\
\text { amongst users }\end{array}$} & $\begin{array}{l}\text { Intensive exploitation (leading to land subsidence, saline or polluted } \\
\text { water intrusion) }\end{array}$ & & & $\checkmark$ \\
\hline & Vulnerable to pollution from land surface (vulnerability, pollution) & & & $\checkmark$ \\
\hline & $\begin{array}{l}\text { Depletion of non-renewable storage (in aquifers with low } \\
\text { contemporary recharge) }\end{array}$ & & $\sqrt{ }$ & \\
\hline \multirow{2}{*}{$\begin{array}{l}\text { Potential water-use conflict but } \\
\text { not at risk of quasi-irreversible } \\
\text { aquifer degradation }\end{array}$} & $\begin{array}{l}\text { With growing large-scale abstraction (especially in aquifers with high } \\
\text { T/S ratios) }\end{array}$ & $\sqrt{ }$ & & \\
\hline & Vulnerable to point-source pollution (vulnerability, pollution) & & & $\checkmark$ \\
\hline \multirow{3}{*}{$\begin{array}{l}\text { Insufficient (or inadequate use } \\
\text { of) scientific knowledge to guide } \\
\text { development policy and process }\end{array}$} & $\begin{array}{l}\text { Potential to improve rural welfare \& livelihoods (not fulfilling MDG } \\
\text { potential) }\end{array}$ & $\sqrt{ }$ & & \\
\hline & Natural quality problems (e.g. As, F) & $\checkmark$ & & \\
\hline & $\begin{array}{l}\text { Scope for large-scale planned conjunctive use (urban W/S or irrigated } \\
\text { agriculture) }\end{array}$ & $\sqrt{ }$ & & \\
\hline
\end{tabular}


water-quality aspects. The following hazards with regards to groundwater supply were identified (GCS, 2006):

- Over-abstraction leading to declining water levels and ground instability

- Point-source contamination

- Non-point-source contamination

- Insufficient supply

- Treatment and reticulation problems

- Prolonged drought conditions

- Recharge with poor-quality surface water

The most likely emergency situations, based on a risk evaluation, were found to be:

- Sinkhole formation and subsidence

- Insufficient water supply

- Water contamination

- Reticulation breakdown and infrastructure breakdown

The knowledge exists to deal with most groundwater management issues. One of the problems is the lack of human-resource capacity to implement the recommendations that follow from numerous studies that have been conducted.

\section{Evaluation of groundwater governance provisions}

The effectiveness of existing governance provisions and capacity to implement adequate groundwater governance is evaluated against a priority list of 20 benchmarking criteria and is listed in Table 4

The evaluation shows that:

- Basic technical provisions such as hydrogeological maps and aquifer delineation with classified typology are in place.

- Other governance provisions across all thematic areas are weak or non-existent:

- Groundwater monitoring is weak and assessment of groundwater resources is poor, both in terms of quantity and quality (e.g. lack of numerical groundwater model).

- There are fair provisions for water-well drilling and groundwater use rights but provisions to control groundwater abstraction and pollution are weak (poor compliance monitoring).

- Provisions for establishment of an aquifer-management organisation are non-existent.

- Cross-sector policy coordination is weak or non-existent.

\begin{tabular}{|c|c|c|c|c|}
\hline \multicolumn{5}{|c|}{$\begin{array}{c}\text { Table } 4 \\
\text { Effectiveness of groundwater governance provisions and capacity in Delmas }\end{array}$} \\
\hline Capacity & Criterion & Context & Provision & $\begin{array}{c}\text { Inst. } \\
\text { capacity }\end{array}$ \\
\hline \multirow{6}{*}{ Technical } & Basic hydrogeological maps & For identification of groundwater resources & 3 & 1 \\
\hline & Groundwater body/aquifer delineation & With classification of typology & 3 & 1 \\
\hline & \begin{tabular}{|l|} 
Groundwater piezometric monitoring \\
network
\end{tabular} & To establish resource status & 2 & 1 \\
\hline & Groundwater pollution hazard assessment & For identifying quality-degradation risks & 1 & 1 \\
\hline & $\begin{array}{l}\text { Availability of aquifer numerical 'manage- } \\
\text { ment models' }\end{array}$ & $\begin{array}{l}\text { At least preliminary for strategic critical } \\
\text { aquifers }\end{array}$ & 0 & 0 \\
\hline & Groundwater quality-monitoring network & To detect groundwater pollution & 1 & 1 \\
\hline \multirow{9}{*}{$\begin{array}{l}\text { Legal and } \\
\text { institutional }\end{array}$} & $\begin{array}{l}\text { Water well drilling permits and groundwater } \\
\text { use rights }\end{array}$ & $\begin{array}{l}\text { For large users, with interests of small users } \\
\text { noted }\end{array}$ & 2 & 1 \\
\hline & \begin{tabular}{|l|}
$\begin{array}{l}\text { Instruments to reduce groundwater } \\
\text { abstraction }\end{array}$ \\
\end{tabular} & Water-well closure/constraint in critical areas & 1 & 1 \\
\hline & \begin{tabular}{|l|}
$\begin{array}{l}\text { Instruments to prevent water well } \\
\text { construction }\end{array}$ \\
\end{tabular} & In overexploited or polluted areas & 2 & 1 \\
\hline & Sanction for illegal water well operation & Penalising excessive pumping above permit & 1 & 1 \\
\hline & Groundwater abstraction and use charging & 'Resource charge' on larger users & 2 & 1 \\
\hline & $\begin{array}{l}\text { Land-use control on potentially polluting } \\
\text { activities }\end{array}$ & $\begin{array}{l}\text { Prohibition or restriction since groundwater } \\
\text { hazard }\end{array}$ & 1 & 0 \\
\hline & $\begin{array}{l}\text { Levies on generation/discharge of potential } \\
\text { pollutants }\end{array}$ & Providing incentives for pollution prevention & 0 & 0 \\
\hline & $\begin{array}{l}\text { Government agency as 'groundwater } \\
\text { resource guardian' }\end{array}$ & Empowered to act on cross-sectoral basis & 1 & 1 \\
\hline & $\begin{array}{l}\text { Community aquifer-management } \\
\text { organisations }\end{array}$ & $\begin{array}{l}\text { Mobilising and formalising community } \\
\text { participation }\end{array}$ & 0 & 0 \\
\hline \multirow{3}{*}{$\begin{array}{l}\text { Cross-sector } \\
\text { policy } \\
\text { coordination }\end{array}$} & Coordination with agricultural development & $\begin{array}{l}\text { Ensuring 'real water saving' and pollution } \\
\text { control }\end{array}$ & 1 & 1 \\
\hline & $\begin{array}{l}\text { Groundwater based urban/industrial } \\
\text { planning }\end{array}$ & $\begin{array}{l}\text { To conserve and protect groundwater } \\
\text { resources }\end{array}$ & 0 & 0 \\
\hline & Compensation for groundwater protection & Related to constraints on land-use activities & 0 & 0 \\
\hline \multirow{2}{*}{ Operational } & $\begin{array}{l}\text { Public participation in groundwater } \\
\text { management }\end{array}$ & $\begin{array}{l}\text { Effective in control of exploitation and } \\
\text { pollution }\end{array}$ & 1 & 1 \\
\hline & $\begin{array}{l}\text { Existence of groundwater management } \\
\text { action plan }\end{array}$ & With measures and instruments agreed & 3 & 0 \\
\hline
\end{tabular}

$0=$ non-existent, 1 = incipient, 2 = fair, $3=$ excellent 
- From an operational point of view, a groundwater management action plan which includes both water-quantity and water-quality aspects exists but has not been implemented to date.

- The Delmas Local Municipality lacks the human-resource capacity to effectively implement groundwater governance provisions. It should also be noted that there is no funding explicitly allocated to groundwater management in the municipal budget.

Specific measures to address potential hazards related to water supply are as follows (GCS, 2006):

- A groundwater protection strategy needs to be developed and implemented within the Delmas area. It should include the establishment of a groundwater model, a monitoring plan and a public-awareness campaign. It should also include the establishment of protection zones around wells and pollution pathways such as sinkholes or swallow holes (sinking streams).

- A groundwater model should be constructed to evaluate the dynamics of the groundwater system with the aim of determining optimum and sustainable groundwater abstraction.

- A monitoring plan and the establishment of a groundwater monitoring network and monitoring schedule are proposed in order to observe the aquifer's response to groundwater abstraction as well as to monitor the water supply (GCS, 2006). The monitoring would include groundwater quantity and quality, surface water and effluent, reticulation systems, and treated water.

- Not only boreholes located in the well-fields, but also selected observation boreholes away from the well-fields have been included in the monitoring programme in order to obtain an insight into 'natural' groundwaterlevel variations. At present, a large number of boreholes are included in the monitoring programme. Optimisation of the monitoring network could take place once more information becomes available.

- Monitoring of geotechnical stability is recommended and includes checking for any possible cracks, subsidence, or other possible early signs of sinkhole formation and subsidence.

- A groundwater-database system should be established. The AQUIMON groundwater-monitoring software package, developed by CSIR and funded by NORAD, is proposed to be used for capturing and storing all the historical and newly collected groundwater data. Quality-assurance procedures are proposed to ensure that the data are checked by the technical manager and the person who captures the data. Every $6^{\text {th }}$ month, the data should be submitted to a qualified hydrogeologist for review, assessment, and to allow for comment and recommendations. The audit also serves as an earlywarning system to check for anomalies in groundwater data, and to make sure that the necessary actions are taken to remedy the situation.

- An awareness campaign should be developed and implemented to educate the public on the impacts of human solid-waste disposal when it is placed into or on any land, open surface holes and streams.

\section{Recommendations for improved governance}

The most critical measures to address existing and potential hazards as well as to improve the effectiveness of existing groundwater governance provisions and institutional capacity are considered:

- The integration of the National Groundwater Strategy into the National Water Resource Strategy, catchment management strategies and other strategies

- Strengthening of the groundwater-related regulatory environment

- Strengthening of the institutional capacity, both in terms of existing institutions (DWA) and establishment

- Operationalising of catchment management agencies (CMAs) and water user associations (WUAs)

Regarding the inadequacy of groundwater expertise we recommend that DWA develop a strategy to augment national groundwater capacity. Furthermore, investigation and implementation of climate-change adaptation measures at local aquifer level are recommended.

Specific recommendations include:

- Strengthening and implementing groundwater governance measures should preferably follow a 'parallel track and adaptive approach' within the existing legal and institutional framework. Such an approach would strengthen the said frameworks without disruption, taking cognizance of the capacity and willingness to implement.

- Pilot projects in the Botleng Dolomite Aquifer to improve the groundwater governance provisions and institutional capacity should focus on implementation constraints at local and regional level (DWA Regional Office (RO) and Delmas Local Municipality (LM)).

- The same methodology which was used in this study can be applied to identify management measures for other aquifer systems in South Africa such as the Karoo Aquifer of Beaufort West.

\section{Acknowledgements}

The South African case study was prepared with support from the World Bank, the South African Department of Water Affairs (DWA) and the Water Research Commission (WRC). It was funded by the Trust Fund for Environmental and Socially Sustainable Development (TFESSD) made available by the governments of Finland and Norway, the Water Partnership Programme and GW-Mate managed by the World Bank. Dr Rafik Hirji, the Task Team Leader of the World Bank, Eng. Hector Garduño and Dr Richard Davis (WB consultants), Mr Ernst Bertram and Ms Nancy Motebe of the Department of Water Affairs, and Mr Jude Cobbing of SLR Metago are particularly thanked for their invaluable guidance and advice during the case study.

The case study greatly benefitted from a multi-stakeholder workshop which was held on 8 November 2010 at the Water Research Commission in Pretoria and which was attended by representatives of the Department of Water Affairs (National and Regional Offices), Water Research Commission, World Bank and the Southern African Development Community.

The authors would also like to thank the reviewers of the paper.

\section{References}

DPLG (DEPARTMENT OF PROVINCIAL AND LOCAL GOVERNMENT, SOUTH AFRICA) (2009) Guidelines for Provinces and Municipalities in the Implementation of the Ward Funding Model. 
Department of Provincial and Local Government, Pretoria, South Africa.

DWA (DEPARTMENT OF WATER AFFAIRS, SOUTH AFRICA) (2009) Green Drop Report 2009 (Version 1) South African Water Quality Management Performance. Department of Water Affairs, Pretoria, South Africa.

DWA (DEPARTMENT OF WATER AFFAIRS, SOUTH AFRICA) (2010) National Groundwater Strategy - Version 1.2. Department of Water Affairs, Pretoria, South Africa.

DWAF (DEPARTMENT OF WATER AFFAIRS AND FORESTRY, SOUTH AFRICA) (1997) White paper on a National Water Policy for South Africa. Department of Water Affairs and Forestry, Pretoria, South Africa.

DWAF (DEPARTMENT OF WATER AFFAIRS AND FORESTRY, SOUTH AFRICA) (2000) Policy and Strategy for Groundwater Quality Management in South Africa ( $1^{\text {st }}$ edn.). Department of Water Affairs, Pretoria, South Africa.

DWAF (DEPARTMENT OF WATER AFFAIRS AND FORESTRY, SOUTH AFRICA) (2004) National Water Resource Strategy $\left(1^{\text {st }}\right.$ edn.). Department of Water Affairs and Forestry, Pretoria, South Africa.

DWAF (DEPARTMENT OF WATER AFFAIRS AND FORESTRY, SOUTH AFRICA) (2006) A Guideline for the Assessment, Planning and Management of Groundwater Resources within Dolomitic Areas in South Africa, Volumes 1-3. Department of Water Affairs and Forestry, Pretoria, South Africa.

DWAF (DEPARTMENT OF WATER AFFAIRS AND FORESTRY, SOUTH AFRICA) (2007) Artificial Recharge Strategy - Version 1.3. Department of Water Affairs and Forestry, Pretoria, South Africa.
FOSTER S, GARDUÑO H, TUINHOF A and TOVEY C (2009) Groundwater Governance - Conceptual Framework for Assessment of Provisions and Needs. GW-Mate Strategic Overview Series No. 1. World Bank, Washington.

GCS (GROUNDWATER CONSULTING SERVICES) (2006) Groundwater Management Plan for Delmas Municipal Council. Report No. 2005.08.399. July 2006.

KOLISA M (2006) What we have learnt from Delmas. Delivery Magazine. URL: http://www.sadelivery.co.za/files/back_issues/ delivery/Edition5/Delmas0111.pdf (Accessed 30 March 2012).

MTHETHWA ZD (2008) Characterisation of Pollution Impacts on the Dolomite Aquifer: Case of Delmas, South Africa. M.Sc. Thesis, Institute of Atmospheric and Environmental Science. School of GeoSciences, University of Edinburgh, UK.

SKM (SINCLAIR KNIGHT MERZ) (2009) Adaptation Options for Climate Change Impacts on Groundwater Resources. Report to World Bank, Washington.

WGC (WATER GEOSCIENCES CONSULTING) (2007) Activity 6 Report: Desktop Geohydrological Assessment of the Delmas/ Bapsfontein Dolomites. Project No. 14/14/5/2: Implementation of Dolomite Guidelines. WGC, Pretoria, South Africa.

WGC (WATER GEOSCIENCES CONSULTING) (2008) Activity 15 Report: Desktop Geohydrological Assessment of the Sudwala/ Pilgrim's Rest Dolomites. Project No. 14/14/5/2: Implementation of Dolomite Guidelines. WGC, Pretoria, South Africa.

WGC (WATER GEOSCIENCES CONSULTING) (2009) Activity 27 Report: Dolomite Technical Series. Project No. 14/14/5/2: Implementation of Dolomite Guidelines. WGC, Pretoria, South Africa. 
http://dx.doi.org/10.4314/wsa.v38i3.11 Available on website http://www.wrc.org.za

ISSN 0378-4738 $($ Print $)=$ Water SA Vol. 38 No. 3 International Conference on Groundwater Special Edition 2012 ISSN 1816-7950 (On-line) = Water SA Vol. 38 No. 3 International Conference on Groundwater Special Edition 2012 